\title{
Ambient air pollution and lung cancer in Poland: research findings and gaps
}

\author{
Mark Parascandola
}

Tobacco Control Research Branch, National Cancer Institute, Rockville, USA

\begin{abstract}
Ambient air pollution is a well established cause of lung cancer. According to a 2016 World Health Organization report on air quality in cities around the world, 33 of the 50 most polluted cities in Europe are in Poland. Moreover, lung cancer is the leading cause of cancer death in Poland. However, there are a number of challenges to understanding the extent of the health burden resulting from high pollution levels in Poland. Challenges include the long lag time between exposure and disease, the difficulties of assessing actual exposure for individuals, limited availability of historical pollution data, and a reliance on risk data from mostly high income countries with different exposure conditions. Additionally, the strong influence of tobacco smoking on lung cancer trends in Poland makes it difficult to isolate the impact of air pollution from other risk factors. Research to date on air pollution and lung cancer in Poland has been limited. Some innovative studies have been conducted in the industrial region of Silesia using molecular markers of DNA damage to demonstrate the biological impact of pollution exposure. Additionally, case control studies and secondary data analyses have provided further documentation of an association between pollution exposure and lung cancer in Poland. However, there is a need for more comprehensive monitoring of air pollution exposure and health effects to be able to assess the cancer burden of air pollution exposure in Poland.
\end{abstract}

KEY WORDS: pollution, lung cancer, Poland.

ADDRESS FOR CORRESPONDENCE: Mark Parascandola, PhD, MPH, Tobacco Control Research Branch, National Cancer Institute, 9609 Medical Center Drive, Rockville MD 20852, USA, e-mail: paramark@mail.nih.gov

Poland's urban air quality is among the worst in the European Union. According to the 2016 World Health Organization Urban Ambient Air Pollution Database, 33 of the 50 most polluted cities in Europe are in Poland
[1]. The situation became front page news in early January 2017. Following a sudden change in weather patterns over Central Europe, temperatures dropped below $-20^{\circ} \mathrm{C}$, leading to increased residential heating use. With

Mark Parascandola is an epidemiologist with the Behavioral Research Program in the Division of Cancer Control and Population Sciences (DCCPS) at the National Cancer Institute (NCI). He also has a secondary appointment in the NCl Center for Global Health. He received his Doctorate in Philosophy of Science from Cambridge University and his Master of Public Health degree in Epidemiology from the Johns Hopkins University School of Hygiene and Public Health. Dr. Parascandola also completed an NCI Cancer Prevention Fellowship. He has authored numerous published articles on epidemiologic research methodology, cancer risk assessment, and tobacco control. He was an editor for the NCI/WHO report The Economics of Tobacco and Tobacco Control (2016) and for the two-volume encyclopedia Tobacco: Its History and Culture (2005). He also served as a member of the IARC Working Group on Methods for Evaluating Tobacco Control Policies in 2007. Dr. Parascandola has served as an Embassy Fellow and expert advisor at the U.S. Embassies in Beijing, China, and Warsaw, Poland, on air pollution and health. He spent 3 months this year in Poland. 
calm wind conditions and widespread reliance on old coal fired stoves, particular matter pollution levels shot up. In some cities in southern Poland, concentrations of PM 2.5 (small size particulates) reached extremely high levels comparable to peak episodes in Beijing or Delhi, including $1600 \mu \mathrm{g} / \mathrm{m}^{3}$ in Rybnik, $1300 \mu \mathrm{g} / \mathrm{m}^{3}$ in Zabrze, $1000 \mu \mathrm{g} / \mathrm{m}^{3}$ in Gliwice, and $700 \mu \mathrm{g} / \mathrm{m}^{3}$ in Katowice. Cities issued smog alerts, provided free public transportation and closed schools [2].

However, understanding the extent of the health burden resulting from high pollution levels in Poland is far more challenging. The European Environment Agency's 2017 "Air Quality in Europe" report estimates there are 46,000 deaths annually due to air pollution in Poland [3]. However, these estimates are based on relatively limited data, applying relative risk estimates from studies in other countries to mortality rates in Poland. While such methods are widely accepted for estimation and planning purposes, they require numerous assumptions, especially for estimating cancer risk. Despite a decrease in lung cancer incidence since 1990 [4], attributed to reductions in cigarette smoking, lung cancer remains the leading cause of cancer mortality among both men and women in Poland [5]. Moreover, substantial disparities remain in lung cancer incidence and mortality; while these differences are largely attributed to patterns of cigarette smoking, they may also be influenced by other factors, including air pollution. Recent reports have even suggested that lung cancer mortality in Poland may be increasing among nonsmokers [6]. However, to date there has been relatively limited study of air pollution exposure and lung cancer in Poland. This paper reviews the evidence to date to identify gaps and future research needs.

\section{AIR POLLUTION AND LUNG CANCER}

Ambient air pollution is a well-established cause of lung cancer [7]. A 2016 IARC monograph concluded that there is sufficient evidence that outdoor air pollution and particulate matter are carcinogenic in humans and that outdoor air pollution specifically causes cancer of the lung. These conclusions are based on findings from several large cohort studies and many case-control studies from North America and Europe dating back to the 1970s. The American Cancer Prevention Study, for example, followed over 500,000 people for over 20 years. Additionally, the IARC report cited other forms of evidence supporting the effects of air pollution on cancer. In particular, ambient air pollution contains specific chemical agents known to cause cancer (including arsenic, cadmium, benzene, beryllium, and polycyclic aromatic hydrocarbons, such as benzo[a]pyrene), and human exposure to outdoor air pollution is associated with forms of genetic damage that are predictive of cancer in humans.

However, a further step is needed to describe the strength of the effect of air pollution exposure on can- cer. In a recent meta-analysis, Huang and colleagues provided such an estimate for the relationship between exposure to PM 2.5 and lung cancer incidence and mortality [8]. Using 17 studies from different countries, they found a relative risk of 1.11 for each $10 \mu \mathrm{g} / \mathrm{m}^{3}$ increase in exposure to PM2.5; in other words, each $10 \mu \mathrm{g} / \mathrm{m}^{3}$ unit increase in PM 2.5 exposure was associated with an $11 \%$ increase in lung cancer. However, because this is a pooled estimate based on multiple studies, the relative risk may vary across countries with different exposure patterns and competing risks. The authors noted that relative risks tended to be higher in studies from Asia compared with Europe. Thus, the analysis provides a benchmark for characterizing the magnitude of risk. Yet estimating the total burden of lung cancer caused by air pollution in a given country requires additional country-specific data.

\section{AIR POLLUTION IN SILESIA, POLAND}

Ten of the most polluted cities in Europe are in the region of Silesia in the south of Poland [9]. The area has a long history of heavy industrial activity. The extended urban area surrounding the city of Katowice is home to 98\% of Poland's coal production, accompanied by coal operated power plants, steel manufacturing, and zinc, lead, and silver mining and processing [10]. Historically, under Soviet influence after World War II, the region was promoted as 'the industrial heart of Poland' where heavy industry and an industrial working class were to be the foundations of a new socialist Poland [11].

A World Bank report from the 1990s authored by Josef Leitmann described the situation shortly after the end of the communist period in Poland. The report described how the Upper Silesian industrial region (USIR), home to $10 \%$ of the population, accounted for nearly $25 \%$ of Poland's GDP and $20 \%$ of exports [12]. The area had the highest employment rate in the country, as well as the highest wages, with some 40,000 factories and manufacturing enterprises. However, the report cautioned that "in terms of many quality-of-life characteristics (environmental indicators, morbidity, mortality), residents of the USIR are among the poorest in the country". The region had the shortest urban life expectancy and the highest incidence of premature births, genetic birth defects, and spontaneous miscarriages in Poland. This situation, Leitmann suggested, was the result of an ongoing pattern of neglect; policies under communist rule emphasized maximizing output but with little investment in long term infrastructure or sustainability, including lack of pollution control measures. Measurements from 1989 recorded average total ambient particulate matter levels in the region ranging from at $300 \mu \mathrm{g} / \mathrm{m}^{3}$ (summer) to $450 \mu \mathrm{g} / \mathrm{m}^{3}$ (winter) [13].

Poland underwent a dramatic social and economic transformation in the post-Communist period and many industrial facilities were closed during the 1990s. 
However, the legacy of industrial pollution remains. Overall pollutant emissions are much lower than they were in 1989, but in some cities the concentrations of particular contaminants remain substantially above recommended levels. Today continued reliance on burning of solid fuels, primarily coal and wood, for home heating accounts for over half of all particulate matter pollution. Geography (hills and valleys that trap pollution) and meteorological conditions (high atmospheric pressure and lack of wind) conspire to promote the formation of smog episodes in Silesia [14]. Recent studies have documented high levels of air pollutants in Silesia, including benzene, heavy metals (cadmium, lead), and fine particulate matter $[15,16]$. Levels of benzo[a]pyrene, a potent carcinogen, are especially high due to burning of coal. So what impact does this legacy of pollution have for lung cancer in Poland?

\section{LUNG CANCER AND AIR POLLUTION STUDIES IN POLAND}

Beginning in the 1980s, a few innovative, early studies were conducted around air pollution and cancer in Poland in collaboration with US investigators. At the time, a new field of molecular epidemiology was emerging, moving beyond in vitro laboratory studies to directly measure genetic damage in human subjects under actual exposure conditions [17]. Building on preliminary laboratory studies [18], epidemiologist Frederica Perera at Columbia University and a multi-disciplinary team of researchers at the Institute of Oncology in Gliwice employed a battery of biological markers to measure molecular and genetic damage in blood samples from residents of Silesia compared to those living in a rural, less polluted area of Poland. The results indicated that pollution exposure was associated with significant increases in carcinogen-DNA adducts, in sister chromatid exchange, and in chromosomal aberrations, all markers of genetic damage relevant to cancer risk [19]. Indeed, levels of pollution-related DNA adducts (binding of chemical molecules to DNA) were two to three times higher among residents of Silesia compared with rural controls. Moreover, the adduct levels in urban Silesian residents were similar to those seen in coke oven workers in the same region, suggesting that ambient pollution exposures were comparable to occupational exposure levels [20]. Seasonal differences in biomarkers were also observed, with higher adduct levels in winter when pollution levels are high due to burning coal for heat [21-23].

Since the 1980s, there have been several epidemiologic studies of air pollution and lung cancer in Silesia and Krakow, where lung cancer rates were known to be high [24], though these studies have yielded mixed results. The first study, a retrospective case-control survey of around 1100 lung cancer deaths (mostly male, along with controls) in Krakow over a six-year period (1980-1985), collected information on occupation, smoking habits, and residence from next of kin and matched that information with local air quality monitoring data for particulate matter and sulphur dioxide. Smoking status had the strongest influence on lung cancer risk, followed by occupational exposure in the iron and steel industries. But ambient air pollution exposure also showed a relative risk of 1.48 for those living in the highest exposure areas. The effect was seen only for men, suggesting a possible combined effect of smoking and occupational exposure. Indeed, for those in the combined exposure categories, exposure to multiple risk factors appeared to confer a multiplicative level of risk [25]. Another study of 600 male lung cancer patients and controls treated at the Institute of Oncology in Gliwice between 1987-1989 compared those living in three different areas of Upper Silesia with varying pollution levels. They found the relative risk of lung cancer was 2.5 times greater for those in the highest pollution area compared with the lowest when controlling for smoking and occupation. Interestingly, they also compared those who were native to the region with those who had immigrated to the region, finding a stronger pollution effect among natives who presumably experienced similar exposure patterns over their entire lifetime [26].

However, a later study including 600 cancer patients and controls diagnosed in Krakow from 1992-1994 failed to find an effect. Classification of exposure to air pollution was based on particular matter and sulphur dioxide data (from 1973 to 1980) from existing monitoring stations. Risk of lung cancer increased significantly with number of pack-years of cigarette smoking $(\mathrm{OR}=18.7$ for more than 40 pack-years) and was also associated with occupational exposure. But no effect on lung cancer risk was seen for air pollution [27].

Other recent studies have looked at ambient air pollution and cancer incidence or overall mortality in Silesia, using existing data to investigate patterns at the aggregate level by subregion. For example, one study compared lung cancer morbidity and pollutant levels among 5 localities and 8 provinces within Silesia using data from the Silesian Cancer Registry and existing air quality monitoring stations. They found an association, among males only, between higher PM10 and benzo[a] pyrene levels and increased lung cancer morbidity [28]. Another recent study looked at associations between long term air pollution exposure and length of life across 19 cities in the Silesian urban agglomeration, an area with over 3.5 million inhabitants. Residents of those cities with historically higher levels of PM10 and benzo[a] pyrene tended to die at younger ages [29]. These findings are noteworthy for providing direct evidence of the impact of air pollution in Poland, though the evidence base here remains limited.

\section{CHALLENGES OF ESTIMATING THE BURDEN}

Several studies have attempted to estimate the mortality burden due to air pollution in Poland [30,31]. However, 
while there is sufficient evidence that ambient air pollution causes lung cancer, estimating the size of the risk and the total cancer burden due to air pollution in a specific population or country is much more difficult. First, there is a long lag time, measured in years or decades, between exposure and cancer incidence or mortality, which makes it difficult to tie trends in cancer statistics to changes in air pollution levels or other risk factors. Historical air pollution data is very limited so that it is difficult to estimate exposure dating back twenty or thirty years. In contrast, it is easier to attribute changes in short term disease effects (such as hospital admissions for respiratory or cardiovascular disease) to air pollution patterns. For example, one hospital in Warsaw during the smog episode in January 2017 reported an increase in hospital admissions for asthma and COPD of more than two times over the previous January [32]. Second, it is difficult to measure actual air pollution exposure for an individual or population, as exposure is influenced not only by place of residence, but other factors such as time spent outdoors, time spent at work versus home or traveling, and daily activities. Additionally, air quality and pollution exposure tend to vary over time with economic trends, seasonal changes, or weather conditions. Sources and characteristics of pollution may also vary by region, which may have implications for health impact. In comparison, tobacco smoke exposure can be estimated more consistently based on the number of cigarettes a person smokes per day [33]. Third, most studies of ambient air pollution and lung cancer come from countries, such as the US and Western Europe, with relatively low exposure levels, which may not correspond in a linear manner to high exposure areas. Fourth, it is important to be able to separate the impact of other competing exposures including cigarette smoking and occupational exposure and potential synergistic effects of combined exposures, which requires having individual level data on smoking and occupational exposure along with pollution exposure.

Using relative risks from US studies, Badyda and colleagues estimated the attributable fraction of lung cancer due to ambient air pollution (PM2.5) exposure to range from $20 \%$ to over $40 \%$ in the 11 largest Polish cities in the years 2006-2011 [34]. Mean annual concentration of PM2.5 varied from 14.3 to $52.5 \mu \mathrm{g} / \mathrm{m}^{3}$, based on official monitoring stations. The lowest concentration was observed in cities of eastern (Bialystok, Lublin) and northern Poland (Gdansk, Szczecin), where the density of emission sources is lower and there are better climatic conditions for dispersion of air pollutants. The highest concentrations occurred in cities in the central and southern regions (Warsaw, Krakow, and Lodz), and these cities were estimated to have the greatest number of PM2.5-attributable deaths. The authors noted several key limitations to their study, including limited air quality data, reliance on relative risks derived from North American epidemiologic studies, and lack of data on influence of other factors, such tobacco use. Thus, substantial uncertainty remains around these estimates.

Lung cancer mortality trends in Poland have undergone substantial change over the past half century. However, these trends appear to be largely explained by changes in cigarette smoking $[35,36]$. Lung cancer mortality tripled among men aged 35-54 between 1960 and the 1980s, but then between 1990 and 2015 fell back to almost the level it had been in 1960. Among women in the same age group, lung cancer mortality rose until 2000 and since then has begun to fall, though not as dramatically as for men. The decrease among men is more dramatic, likely because their levels of smoking increased earlier and reached a higher peak compared with women. Tobacco consumption in Poland began to decrease during the economic crisis of the 1980s and continued with tobacco control efforts in the 1990s [37]. Broad geographic trends can also be seen in Poland, with higher lung cancer mortality in the north and west of Poland where cigarette smoking has been higher compared with the east [38]. In contrast, ambient air pollution levels have historically been highest in the south where lung cancer mortality is lower. Overall, the rise and fall of lung cancer mortality and divergence between men and women and geographic regions support the conclusion that cigarette smoking has been the primary driver of overall lung cancer trends in Poland.

Overall, the dominant influence of cigarette smoking on lung cancer largely obscures any role for air pollution. Nevertheless, given the ongoing high pollution levels in Poland and the established role of air pollution as a cause of lung cancer, it can be presumed that ambient air pollution does account for some portion of lung cancer in Poland, possibly in combination with cigarette smoking and occupational exposures. But, unfortunately, the necessary data sources and studies to estimate the size of this burden are lacking in Poland. Addressing the following gaps could provide for more in depth assessment of the burden of air pollution on lung cancer in Poland:

- Epidemiologic studies: Due to the lack of epidemiologic studies in Poland, estimates of the impact of air pollution on lung cancer have relied on relative risks from studies from other parts of the world, where exposure conditions may be different. There have been no prospective cohort studies of air pollution exposure with cancer outcomes in Poland. One cohort study conducted in Krakow, led by Frederica Perera, has measured maternal exposure to specific pollutants and child health outcomes, including cognitive dysfunction [39]. A few case control studies and ecologic studies using existing datasets exist in the literature, as described above, but findings are inconsistent and have substantial limitations due to the challenges in estimating historical exposure. Given that much of the existing epidemiologic research on cancer risks of air pollution comes from the US and Western Europe, 
where pollution levels are generally lower than in Poland and sources and characteristics of pollution may differ, conducting epidemiologic cohort studies in Poland would add substantial value to the evidence base.

- Air quality monitoring: The number of official air quality monitoring stations in Poland has increased in the years since Poland joined the European Union [40]. However, the number of measuring stations remains limited mostly to major cities and large areas of the country are not covered. While the lack of historical data cannot be corrected retroactively, increasing coverage of the monitoring network would be an important resource for future studies. For example, a recent US analysis was able to demonstrate an association between air pollution and lung cancer mortality at the county level, largely because of the availability of local data [41]. One promising avenue is the development of inexpensive technologies and mobile apps to increase air quality data collection and availability [42].

Air pollution is a serious and preventable cause of lung cancer, and especially important to address in places where air pollution remains high, such as Poland. The explosion in public awareness and concern over air pollution in Poland over the past year has given a sense of urgency to the problem. Yet in order to address the issue in a comprehensive way, and to measure the impact of any future interventions, ongoing monitoring and further research efforts are critically needed.

\section{DISCLOSURE}

The author reports no conflict of interests.

\section{References}

1. WHO Global Urban Ambient Air Pollution Database (update 2016). Available from: http://www.who.int/phe/health_topics/ outdoorair/databases/cities/en/ (accessed: 10 May 2018).

2. Durka P, Kaminski JW, Struzewska J. Air pollution in Polish cities during January 2017 - an episode study. Geophysical Research Abstracts 2017; 19: 16041.

3. European Environment Agency. Air Quality in Europe - 2017 report. Publications of the Office of the European Union, Luxembourg 2017. Available from: https://skupnostobcin. si/wp-content/uploads/2017/10/airquality2017-15-29.pdf (accessed: 10 May 2018).

4. Didkowska J, Manczuk M, McNeill A, Powles J, Zatonski W. Lung cancer mortality at ages 35-54 in the European Union: Ecological study of evolving tobacco epidemics. BMJ 2005; 331: 189-191.

5. National Cancer Registry (Poland). Available from: http:// onkologia.org.pl/raporty/ (accessed: 10 May 2018).

6. Wantuch D. Smog a nowotwory płuc. Onkolodzy biją na alarm [Smog and lung cancer: Oncologists are beating the alarm]. Wyborcza.pl. February 27, 2016. Available from: http://wyborcza. pl/akcje_specjalne/1,155201,19687020,smog-a-nowotworypluc-onkolodzy-bija-na-alarm.html (accessed: 10 May 2018).
7. International Agency for Research on Cancer. Outdoor Air Pollution. IARC Monographs on the Evaluation of Carcinogenic Risks to Humans, Volume 109. IARC, Lyon 2016. Available from: http://monographs.iarc.fr/ENG/Monographs/vol109/index.php (accessed: 10 May 2018).

8. Huang F, Pan B, Wu J, Chen E, Chen L. Relationship between exposure to PM2.5 and lung cancer incidence and mortality: A meta-analysis. Oncotarget 2017; 8: 43322-43331.

9. WHO 2016 WHO Ambient Air Pollution Database. Available from:http://apps.who.int/iris/bitstream/handle/10665/250141/ 9789241511353-eng.pdf;jsessionid=D90E7E11BA87FAC530 CCF8143DC4A6E1? sequence=1 (accessed: 10 May 2018).

10. Norska-Borówka I. Poland: Environmental pollution and health in Katowice. Lancet 1990; 335: 1392-1393.

11. Murzyn-Kupisz M, Gwosdz K. The changing identity of the Central European city: the case of Katowice. Journal of Historical Geography 2011; 37: 113-126.

12. Leitmann J. Katowice. Cities 1994; 11: 147-152.

13. Pastuszka J, Hlawiczka S, Willeke K. Particulate pollution levels in Katowice, a highly industrialized Polish city. Atmospheric Environment. Part B. Urban Atmosphere 1993; 27: 59-65.

14. Badyda A, Dąbrowiecki P. Smog episode in Poland in January 2017 as a risk factor of increased hospital admissions due to respiratory and cardiovascular exacerbations. Eur Respir J 2017; 50: PA2630.

15. Dziubanek G, Marchwińska-Wyrwał E, Ćwieląg-Drabek M, Spychała A, Rusin M, Piekut A, Hajok I. Preliminary study of possible relationships between exposure to PCDD/Fs and dl-PCBs in ambient air and the length of life of people. Sci Total Environ 2017; 598: 129-134.

16. Chorazy M, Szeliga J, Strozyk M, Cimander B. Ambient air pollutants in upper Silesia: partial chemical composition and biological activity. Environ Health Perspect 1994; 102: 61-66.

17. Motykiewicz G, Perera FP, Santella RM, et al. Assessment of cancer hazard from environmental pollution in Silesia. Toxicol Lett 1996; 88: 169-173.

18. Chorąży M, Szeliga J, Stróżyk M, Cimander B. Source. Ambient Air Pollutants in Upper Silesia: Partial Chemical Composition and Biological Activity. Environ Health Perspect 1994; 102 Suppl 4: 61-66.

19. Perera FP, Hemminki K, Gryzbowska E, et al. Molecular and genetic damage in humans from environmental pollution in Poland. Nature 1992; 360: 256-258.

20. Hemminki K, Grzybowska E, Chorazy M, et al. DNA adducts in human environmentally exposed to aromatic compounds in an industrial area of Poland. Carcinogenesis 1990; 11: 12291231.

21. Motykiewicz G. Application of biomarkers in heavily polluted industrialized areas of countries of central and Eastern Europe. Toxicology 1995; 101: 117-123.

22. Motykiewicz G, Szeliga J, Cimander B, Chorąży M. Seasonal variations in mutagenic activity of air pollutants at an industrial district of Silesia. Mutat Res 1989; 223: 243-251.

23. Pendzich J, Motykiewicz G, Michalska J, et al. Sister chromatid exchanges and high-frequency cells in men environmentally and occupationally exposed to ambient air pollutants: an inter- 
group comparison with respect to seasonal changes and smoking habit. Mutat Res 1997; 381: 163-170.

24. Jedrychowski W, Szal H, Cholewka-Cabaj K. Monitorowanie zachorowań na raka płuca wśród mieszkańców Krakowa na podstawie danych o przyczynach zgonu [Monitoring the incidence of lung cancer among the population of Cracow based on the data of cause of death]. Przegl Lek 1984; 41: 309-314.

25. Jedrychowski W, Becher H, Wahrendorf J, Basa-Cierpialek Z. A case-control study of lung cancer with special reference to the effect of air pollution in Poland. J Epidemiol Commun Health 1990; 44: 114-120.

26. Zemia B. Ambient air pollution, tobacco smoking and occupational exposure in relation to lung cancer among natives and immigrants population in Upper Silesia Region. Lung Cancer 1997; 18: 194

27. Pawlega J1, Rachtan J, Dyba T. Evaluation of certain risk factors for lung cancer in Cracow (Poland) - a case-control study. Acta Oncol 1997; 36: 471-476.

28. Kapka L, Zemła BF, Kozłowska A, Olewińska E, Pawlas N. Jakość powietrza atmosferycznego a zapadalność na nowotwory płuc w wybranych miejscowościach i powiatach województwa śląskiego [Air quality vs morbidity to lung cancer in selected provinces and localities of the Silesian Region]. Przegl Epidemiol 2009; 63: 439-444.

29. Dziubanek G, Spychała A, Marchwińska-Wyrwał E, et al. Longterm exposure to urban air pollution and the relationship with life expectancy in cohort of 3.5 million people in Silesia. Sci Total Environ 2017; 580: 1-8.

30. Samek L. Overall human mortality and morbidity due to exposure to air pollution. Int J Occup Med Environ Health 2016; 29: 417-426.

31. Holnicki P, Tainio M, Kałuszko A, Nahorski Z. Burden of disease due to air pollutants emitted from urban sources in Warsaw, Poland. Raport Badawczy Research Report RB/2/2017. Available from: Systems Research Institute, Polish Academy of Sciences. Available from: http://www.ibspan.waw.pl/ kaluszko/RB-2-2017.pdf (accessed: 10 May 2018).

32. Badyda A, Dąbrowiecki P. Smog episode in Poland in January 2017 as a risk factor of increased hospital admissions due to respiratory and cardiovascular exacerbations admissions due to respiratory and cardiovascular exacerbations. Eur Respir J 2017; 50: PA2630.

33. Soulakova JN, Hartman AM, Liu B, et al. Reliability of adult self-reported smoking history: Data from the Tobacco Use Supplement to the Current Population Survey 2002-2003 cohort. Nicotine Tob Res 2012; 14: 952-960.

34. Badyda AJ, Grellier J, Dąbrowiecki P. Ambient PM2.5 Exposure and Mortality Due to Lung Cancer and Cardiopulmonary Diseases in Polish Cities. Adv Exp Med Biol 2017; 944: 9-17.

35. Zatonski WA, Zatonski M. Poland's rapid lung cancer decline in the years 1990-2016: The first steps towards the eradication of lung cancer in Poland. Health Prob Civil 2017; 11: 211-225.

36. Kubik AK, Parkin DM, Plesko I, et. al. Patterns of cigarette sales and lung cancer mortality in some central and eastern European countries, 1960-1989. Cancer 1995; 75: 2452-2460.
37. Jassem J, Przewozniak K, Zatonski W. Tobacco control in Poland - successes and challenges. Transl Lung Cancer Res 2014; 3 : 280-285.

38. Ministry of Health (Poland). Global Adult Tobacco Survey Poland 2009-2010. Ministry of Health, Warsaw 2010. Available from: http://www.who.int/tobacco/surveillance/en_tfi_gats_poland_ report_2010.pdf (accessed: 10 May 2018)

39. Jedrychowski WA, Perera FP, Camann D, et al. Prenatal exposure to polycyclic aromatic hydrocarbons and cognitive dysfunction in children. Environ Sci Pollut Res Int 2015; 22: 36313639.

40. World Health Organization Europe. Environment and Healt Performance Review Poland. World Health Organization, Geneva 2009. Available from: http://www.euro.who.int/_data/assets/ pdf_file/0005/95333/E92584.pdf (accessed: 10 May 2018).

41. Moore JX, Akinyemiju T, Wang HE. Pollution and regional variations of lung cancer mortality in the United States. Cancer Epidemiol 2017; 49: 118-127.

42. McKercher GR, Vanos JK. Low-cost mobile air pollution monitoring in urban environments: a pilot study in Lubbock, Texas. Environ Technol 2018; 39: 1505-1514. 